\title{
Early changes of placenta-derived messenger RNA in maternal plasma - potential value for preeclampsia prediction?
}

\section{Modificările precoce ale ARN-ului mesager de origine placentară în plasma maternă - potențiala valoare în predicția preeclampsiei?}

\author{
Sebastian Surugiu ${ }^{1}$, Adina Chis ${ }^{2}$, Codruta Mare ${ }^{3}$, Horea Matei ${ }^{2 *}$, Florin \\ Stamatian ${ }^{1}$
}

1. Department of Mother and Child, "Iuliu Hatieganu” University of Medicine and Pharmacy; 2. Department of Cell and Molecular Biology, "Iuliu Hatieganu” University of Medicine and Pharmacy, Cluj-Napoca, Romania; 3. Depatment of Statistics, Forecasting , Mathematics, Faculty of Economics and Business, "Babes-Bolyai" University, Cluj-Napoca, Romania

\begin{abstract}
Objective: the pourpose of the study was to determine if there are any differences between placenta derived plasmatic levels of messenger RNA in normal and future preeclamptic pregnancies and if these placental transcripts can predict preeclampsia long before clinical onset

Study design: we compared plasmatic expression of two placental transcripts from 12 women who ultimately developed preeclampsia with 224 controlled subjects, at the end of the first trimester of pregnancy. After multiplse-of-the-median conversion of markers we developed a multivariate model using logistic regression to determine preeclampsia risk.

Results: we found lower multiples of the median values for both placental transcripts (mRNA corresponding to placental growth factor and pregnancy associated plasmatic protein A) in cases who ultimately developed preeclampsia and the multivariate model we obtained offered a preeclampsia detection rate of $75 \%$ at $10 \%$ false positive rate.

Conclusion: specific early changes of placenta-derived messenger RNA could be used as preeclampsia predictors.

Keywords: messenger RNA, nucleic acids, pregnancy, preeclampsia, prediction

\section{Rezumat}

Obiectiv: scopul studiului a fost acela de a determina dacă există diferențe între nivelurile plasmatice ale $A R N$-ului mesanger de origine placentară în plasma materna între sarcinile normale și cele complicate ulterior cu
\end{abstract}

\footnotetext{
*Corresponding author: Horea Matei, Department of Cell and Molecular Biology, "Iuliu Hatieganu" University of Medicine and Pharmacy, Cluj-Napoca, Romania, e-mail: horea_matei@yahoo.com
} 
preeclampsie și dacă aceste transcripte placentare pot prezice instalarea preeclampsiei înainte de debutul clinic al bolii.

Design-ul studiului: am comparat expresia plasmatică a doua transcripte placentare provenind de la 12 cazuri care au dezvoltat ulterior preeclampsie cu cea constatată la 224 cazuri martor, la finalul primului trimestru de sarcină. După conversia markerilor în multipli ai medianei am dezvoltat un model multivariat folosind regresia logistică pentru a determina riscul de preeclampsie.

Rezultate: am constatat valori mai mici ai multiplilor medianei pentru ambele transcripte placentare analizate (ARN-ul mesager corespunzător factorului de creștere placentar și proteinei plasmatice A asociată sarcinii) în cazurile care au dezvoltat ulterior preeclampsie, iar modelul multivariat obținut a permis o predicție a preeclampsiei de $75 \%$ la o rată a rezultatelor fals pozitive de $10 \%$.

Concluzie: modificările specifice ale transcriptelor placentare în plasma maternă ar putea fi utilizate ca și predictori ai instalării preeclampsiei.

Cuvinte cheie: ARN mesager, acizi nucleici, sarcina, preeclampsie, predictie

Received: 15 $5^{\text {th }}$ March 2015; Accepted: 29 $9^{\text {th }}$ September 2015; Published: $2^{\text {nd }}$ December 2015

\section{Introduction}

Preeclampsia, a condition that affects $2-10 \%$ of all pregnancies worldwide, continues to remain one of the most important causes of fetal and maternal morbidity and mortality (1). Preeclampsia, whose clinical manifestations appear after $20^{\text {th }}$ week of pregnancy, is known for having a long preclinical stage, in which fundamental molecular events take place, offering a time-window for detecting those pregnancies destined to develop the disease and, consequently, offering those at risk intensive maternal and fetal monitoring. Although the central role played by the placenta in disease's pathogeny is known for a long time, only recent data showed the influence of the pro- and antiangiogenic factors imbalance that will end up in lower levels of placental growth factor (PIGF) (2-4), the main local proangiogenic, and higher levels of solube fms-like tyrosine kinase 1 (Flt-1) and endoglin, known for their antiangiogenic properties $(5,6)$, resulting in an altered trophoblastic invasion into the uterine spiral arteries. Another molecule involved in local regulation of trophoblastic arterial invasion is pregnancy-associated plasmatic protein $\mathrm{A}$, a syncytiotrophoblast-derived protease that acts as a binding molecule for insulin-like growth factor (7) and there is evidence that PAPP-A and PIGF plasmatic concentrations are lower at an early pregnancy age in many of the cases destined to develop preeclampsia (8-10). In fact these two proteins are currently used in the successful screening of preeclampsia, along with uterine Doppler examination and elements derived from maternal history (11).

As a result of abnormal trophoblastic vascular invasion, a raise of the necrotic-apoptotic activity into the placentation area at the utero-placental interface will develop, resulting in release of micro- and nanoparticles of trophoblastic origin, containing nucleic acids $(12,13)$ in the maternal blood stream. The presence of placental messenger RNA into the maternal circulation, reported for the first time by $\mathrm{Ng}$ et al (14), offered new perspectives for clinical use in prenatal diagnosis and placental genetic expression profiling. The rapid clearance of the messenger RNA species from maternal blood after delivery confirms their origin from the actual pregnancy (14). On the other hand, Tsui et al (15), cited by Farina (16), demonstrated that the maternal profile of some of the placental transcripts does not depend strictly on the placental genetic expression, possibly due to the variable localization of different mRNAs in the inner and outer trophoblastic layers. 
Given the proven placental origin and the intrinsic stability of these molecules, their expression profile in the maternal blood or plasma has been evaluated by several studies in preeclamptic pacients in attempts to identify a specific gene or set of genes associated with the disease. These studies, recently reviewed by Farina (16), although showed differences between normal and preeclamptic pregnancies for different placental transcripts, failed to identify a specific "preeclamptic" profile and offered rather pathophysiological considerations, based on populational data that were, in fact, collected with much variability. Only very few studies analyzed the plasmatic expression of several placental mRNA species long before the clinical onset of preeclampsia and reported detection rates between $60-80 \%$ at al false positive rate of $5 \%$, using different panels of placental transcripts in multivariate models (16). The most studied genes were PLAC1, PLAC3, PLAC4, Flt1, endoglin, PIGF, placental protein-13 (PP-13), corticoptropine releasing hormone - $\mathrm{CRH}$, but for many of these placental transcripts, the association between their final proteic products and preeclampsia risk is already known (8-10).

To date there is no large scale clinical study to evaluate the potential of the placenta-derived mRNA species as biomarkers for preeclampsia screening, nor any proof of their superiority compared to the proteic markers in early prediction of the disease. It has been suggested by Okazaki et al that cellular mRNA is not as useful as plasmatic mRNA (17) and Heung et al (18) stated that many of the placental transcripts dosed in whole blood might be, in fact, of maternal origin, derived from processes such as "illegitimate transcription", advocating that maternal plasma could be a more accurate source of placental nucleic acids, in particular mRNA.

In our prospective screening study we have evaluated the early changes in maternal plasma and the predictive value of 2 species of placen- ta-derived mRNA, corresponding to PIGF and PAPP-A, along with elements from maternal history for preeclampsia prediction, at the end of the first trimester of pregnancy. As stated above, the preeclampsia risk associated to these two proteins concentrations is known, but there is inconsistent data regarding plasmatic changes of their mRNA at the end of the first trimester of pregnancy, when preeclampsia screening can be performed. Two studies mentioned lower values for PIGF mRNA in pregnancies destined to develop preeclampsia $(19,20)$ and we found no study to evaluate PAPP-A mRNA changes in maternal plasma at an early gestational age in cases consequently complicated by preeclampsia.

\section{Material and methods}

Participants. The studied population consisted of 250 singleton pregnant women (primiparas and only secundiparas with preeclamptic first pregnancy) who attended Obstetrics and Gynecology I Clinic, Cluj-Napoca, Romania, for first trimester aneuploidy screening (double-test), performed at $11-13+6$ gestational weeks. Gestational age was calculated by the first day of the last menstruation and confirmed by ultrasound measurement of the fetal crown-rump length.We included in the study only cases in which no aneuploidy or fetal major defects were suspicioned at that time. All cases provided informed consent to participate to the study, which was approved by the Ethics Committee of the University of Medicine and Pharmacy, Cluj-Napoca, Romania. All subjects offered information regarding age, previous abortions, comorbidities, cigarette consumption, height and weight were measured and body mass index (BMI) was calculated for each case.

Clinical assessment. Preeclampsia was defined as gestational hypertension (systolic blood pressure $\geq 140 \mathrm{~mm} \mathrm{Hg}$ and/or diastolic blood pressure $\geq 90 \mathrm{~mm} \mathrm{Hg}$ ) associated with pro- 
teinuria (defined as $>0,3 \mathrm{~g} / \mathrm{dl}$ in 24 hours urine specimen) after 20 weeks of pregnancy. Severe preeclampsia was defined, according to the National Institute for Care and Clinical Excellence severity clasification (21), as systolic blood pressure $\geq 160 \mathrm{~mm} \mathrm{Hg}$ and/or diastolic blood pressure $\geq 110 \mathrm{~mm} \mathrm{Hg}$, keeping the same cut-off value for proteinuria. Early-onset preeclampsia was defined as clinical manifestations before 34 weeks of pregnancy, while late-onset preeclampsia was defined as clinical manifestations after 34 weeks.

Total RNA isolation and RT-qPCR. RNA was extracted from plasma (EDTA-anticoagulated blood) using MasterPureTM Complete DNA and RNA Purification Kit ${ }^{2}$ (Epicentre ${ }^{\circledR}$, Madison, USA), following manufacturer's instructions and then kept at $-86^{\circ} \mathrm{C}$. The plasmatic RNA concentration was determined using an ImplenNanoPhotometer, (Scimetrics Inc., Huston, TX, USA) and expressed as $\mu \mathrm{g} / \mathrm{ml}$. In the next phase, the placenta-derived mRNA for both genes (phosphatidylinositol glycan anchor biosynthesis, class F- PIGF and pregnancy-associated plasma protein $A$ - PAPP-A) were amplified by quantitative real-time polymerase chain reaction (RT-qPCR) using a RT-PCR Light Scanner 32 device (Idaho Technology Inc., Utah, USA). Briefly, the RT-qPCR assay conditions were optimized as follows: each reaction was carried out in a $10 \mu \mathrm{l}$ volume [20 ng of RNA; $5 \mu 1$ of 2xqRT-PCR MasterMix (PrimerDesign, UK); $3.5 \mu \mathrm{l}$ of ultrapure water; the forward primer (5'-GATTTCAGGAGCCACAGAAGAA-3' for PAPP-A gene and 5'-GCAACTTACATACAA GAACAATTAACT- 3' for PIGF gene)] and reverse primer $\left(5^{\prime}\right.$-AATAGATGATGATGG GAGTGAAGATA-3' for PAPP-A gene and 5' -GTAAATGGAACTGCTTGGCTTT- 3' for PIGF gene) (PrimerDesign, UK)]. For both genes, the thermal cycling consisted of 10 minutes of revers transcription at $55^{\circ} \mathrm{C}, 10$ minutes of activation followed by 50 cycles of $95^{\circ} \mathrm{C}(10 \mathrm{~s})$ and $60^{\circ} \mathrm{C}(5 \mathrm{~s})$. Taqman PCR analyses for PIGF and PAPP-A were performed with predeveloped and commercially available DNA primers and probe sets, produced by PrimerDesign (United Kingdom). The specific mRNA for each genes were expressed as copies per milliliter, based on the standard curves obtained by performing RT-PCR using a 10 -fold serial dilution series.

Statistical Analysis. Data analysis was performed using SPSS 20 software. Concentrations of both placental markers were expressed as multiples of median (MoM) converted into Log10 scale. We calculated the detection rate and false-positive rate for each placental transcript with a univariate receiver operating characteristic (ROC) curve. Additionally, multivariate analysis was performed using logistic regression (Forward method) with the aim of pulling together the detection rate of each statistically significant marker and the multivariate ROC curve was built to calculate the preeclampsia risk for each patient. The significance of the results of our regression model was confirmed using several validation test, such as the Hosmer-Lemeshow statistics.

\section{Results}

Table I shows the demographical characteristics of pregnant women from preeclampsia and control groups. Preeclampsia occurred in 12 cases $(4.8 \%)$, out of which 5 cases developed early-onset, severe preeclampsia and 7 cases developed late-onset form, 11 cases left the study (4.4\%); 3 cases developed gestational hypertension $(1.2 \%)$ and were excluded from the statistical analysis and 224 had normal pregnancies $(89.6 \%)$. We noted significant differences in BMI, gestational age at delivery, fetal weight at birth and the presence of a previous miscarriage (negative correlation). These results are consistent with the existing information in the literature. No significant differences in age, smoking 
Table I. Demographic characteristic. Data are expressed as mean \pm standard deviation

\begin{tabular}{lccccc}
\hline \multirow{2}{*}{} & \multicolumn{2}{c}{ No } & \multicolumn{2}{c}{ Preeclampsia } & \multirow{2}{*}{ Yes } \\
\cline { 2 - 5 } & $\mathrm{N}$ & & $\mathrm{N}$ & \\
\hline Age (years) & 224 & $29.67 \pm 4.25$ & 12 & $30.33 \pm 4.47$ & 0.602 \\
\hline Weight $(\mathrm{kg})$ & 224 & $62.13 \pm 10.77$ & 12 & $68.28 \pm 10.98$ & 0.055 \\
\hline Height $(\mathrm{m})$ & 224 & $1.65 \pm 0.05$ & 12 & $1.64 \pm 0.03$ & 0.555 \\
\hline Body mass index $\left(\mathrm{kg} / \mathrm{m}^{2}\right)$ & 224 & $22.63 \pm 3.58$ & 12 & $25.19 \pm 3.82$ & 0.017 \\
\hline Gestational age at delivery (weeks) & 223 & $38.91 \pm 1.75$ & 12 & $36.50 \pm 2.94$ & 0.016 \\
\hline Gestational age at enrolling (weeks) & 223 & $12.28 \pm 0.91$ & 12 & $12.09 \pm 0.57$ & 0.482 \\
\hline Fetal birthweight $(\mathrm{g})$ & 224 & $3300.76 \pm 553.25$ & 12 & $2535.83 \pm 972.22$ & 0.020 \\
\hline
\end{tabular}

Table II. LogMom values of the placental transcripts in preeclamptic cases and controls. Data are expressed as mean \pm standard deviation

\begin{tabular}{cccccc}
\hline & \multicolumn{4}{c}{ Preeclampsia } & \multirow{2}{*}{ p-value } \\
\cline { 2 - 5 } & \multicolumn{2}{c}{ No } & & Yes & \\
\cline { 2 - 6 } & $\mathrm{N}$ & & $\mathrm{N}$ & $<0.001$ \\
\hline LOG MOM PIGF copii & 224 & $-0.1058 \pm 1.05754$ & 12 & $-1.0381 \pm 0.33730$ & $<0.001$ \\
\hline LOG MOM PAPP-A copii & 224 & $-0.5164 \pm 1.03349$ & 12 & $-2.0015 \pm 0.32379$ & $<$ \\
\hline
\end{tabular}

status or gestational age at enrolling was emphasized. Differences between the two groups were parametrically tested based on median values. Table II shows the $\log$ values of the median for both placental transcripts that have been analyzed in our study. Our results show that, at 11-13+6 weeks of gestation, women who will subsequently develop preeclampsia have significantly lower plasmatic levels of both PIGF mRNA and PAPP-A mRNA compared to those who will have normal pregnancies.

The logistic regression validated as the best fitted multivariate model the one combining BMI, PIGF mRNA and PAPP-A mRNA plasmatic concentrations. The following score function was obtained:

$$
\mathrm{Y}=-8.718+0.182 \times \mathrm{xMI}-0.918 \times \log -
$$
MoM-PAPP-A - 0.579xlogMoM-PIGF.

The ROC curve we obtained using the estimated individual risk for preeclampsia yielded a sensitivity of $33 \%$ at a $5 \% 1$-specificity rate, re- spectively a sensitivity of $75 \%$ at a $10 \% 1$-specificity rate, with an area under the curve of 0.921 ([0.882;0.961] - 95\% CI; $p<0.001)$. (Figure 1).

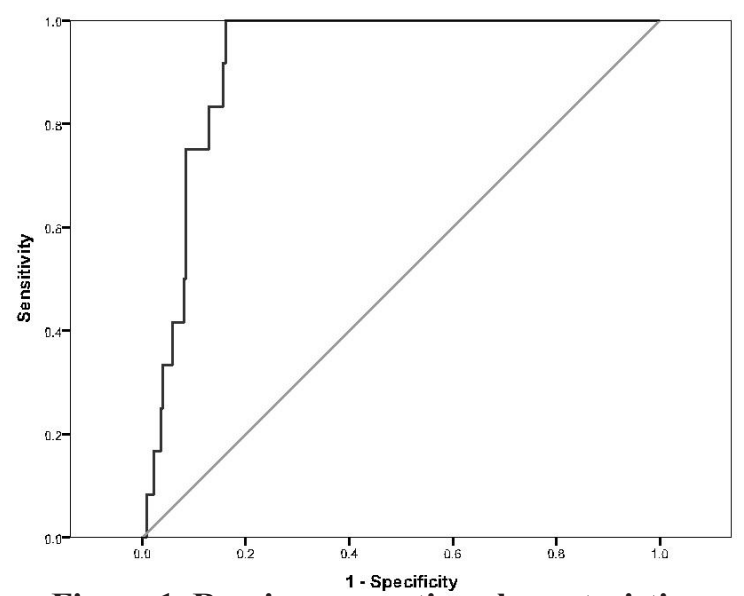

Figure 1. Receiver operating characteristic (ROC) curve. A multivariate model consisting of BMI, PIGF mRNA and PAPP-A mRNA concentrations was used to generate the ROC curve. 


\section{Discussion}

Our study evaluated the expression of 2 species of cell-free placental messenger RNA into the maternal plasma at 11-13+6 weeks of pregnancy and assessed the subsequent preeclampsia risk. We chose the transcripts of two genes whose final proteic products are involved in the complex processes of placental development and vasculogenesis, whereof the existing information published in the literature showed a statistically-proven association with preeclampsia risk. At the mentioned gestational age these two proteins present altered plasmatic concentrations in many of the cases destined to develop a preeclamptic syndrome and they are already successfully used in preeclampsia screening programs. Our results suggest, similar to other studies published in the existing literature, that early changes in placental transcripts plasmatic concentrations are present in those cases at risk for preeclampsia, these changes can be assessed by laboratory techniques and different placental mRNA species could be used in the future as an effective screening tool to predict preeclampsia development.

The few studies published up to date, that approached on a limited number of cases the predictive value of certain placenta-derived messenger RNA species, suggest that preeclampsia risk could be assessed by simultaneously assay of different placental transcripts, more probable of those directly involved in the complex placental developmental process. Purwosunu et al (22) evaluated the combined predictive value of seven placental transcripts determined in maternal plasma (Flt1, endoglin, SERPINE1, PLAT, VEGF-A, SELP, PLAC1) at 15-20 weeks of gestation. They obtained a multivariate predictive model that allowed preeclampsia prediction at a sensitivity of $88.7 \%$ at a false-positive rate of $10 \%$. Sekizawa et al (19) assessed the early changes in maternal whole blood and predictive value of certain placental transcripts involved in placental angiogenesis and oxidative stress (P-selectin, PLAC1, Flt1, endoglin, HO-1 and PIGF) at the same gestational age. They noticed higher levels of P-selectin, PLAC1, Flt1 and endogline, and lower levels for HO-1 and PIGF in pregnancies complicated by preeclampsia and reported a detection rate of $84 \%$ at a false positive rate of 5\%. Farina et al (20) evaluated the early changes in maternal whole blood and predictive value of 5 species of placental mRNA (Flt1, endoglin, PIGF, transforming growth factor $\beta 1$ - TGF- $\beta 1$ and PP-13) at 10-14 weeks of pregnancy. The authors showed that women destined to develop preeclampsia had higher levels of Flt1, endoglin and TGF- $\beta 1$ mRNA and lower levels of PIGF and PP-13 mRNA. Based on their findings they generated a multivariate model able to predict preeclampsia risk from this early pregnancy age with a sensitivity of $72.3 \%$ at a false-positive rate of 5\%.

Another class of RNA molecules of placental origin, besides mRNA, that recently came to attention is represented by microRNA species. A single observation made so far, published by Anton et al (23), suggests that miR-210 might present early concentration changes long before clinical manifestations of preeclampsia, thus showing a potential predictive value.

The studies that evaluated early changes of placental transcripts in maternal circulation are sparse and include only small numbers of cases, assessing mRNA either in maternal plasma or in whole blood. Since it has been hypothesized that plasma is a more accurate source of placental transcripts than the whole blood (18), yet unconfirmed by subsequent studies, the most adequate nucleic acid source (whole blood vs. plasma) still needs to be specified. Preeclampsia is considered today a predictable disease, starting from the first trimester of pregnancy, using combined screening, as the described in the introduction (11). Approaching preeclampsia screening by 
using placenta-derived nucleic acids, although it delivered promising results, still carries numerous uncertainties, including the best placental mRNA source and the most appropriate gestational age to perform the laboratory assessment. Since to date there is no large scale clinical study that assessed the early changes of these molecules in future preeclamptic pregnancies, it is yet presumable that a preeclampsia-prediction model based on placental-derived mRNA species with similar efficiency as the combined screening would involve simultaneous dosage of a big number of placental transcripts, yet in an unspecified configuration.

In conclusion, we showed that mRNA expression levels in maternal plasma of placental growth factor (PIGF) and pregnancy-associated plasmatic protein A (PAPP-A) are lower at 11$13+6$ weeks of pregnancy in cases with future preeclampsia and that it is possible to demonstrate early changes of the placental transcriptome in those cases destined to develop preeclampsia using laboratory methods that are non-invasive on the fetal-placental unit and also to predict preeclampsia development.

\section{Abbreviations}

Flt1 - FMS like tyrosine kinase

PAPP-A pregnancy-associated plasmatic protein

A

PIGF - placental growth factor

RNA - ribonucleic acid

PLAC - placental specific

PP 13 - placental protein 13

$\mathrm{CRH}$ - corticotropine releasing hormone

DNA - desoxiribonucleic acid

RT - qPCR - quantitative real-time polymerase chain reaction

VEGF-A - vascular endothelial growth factor A

HO-1 - hemaglutinin oxidase 1

PLAT - plasminogen activator tissue

TGF $\beta$ - transforming growth factor beta

\section{References}

1. Osungbade KO, Ige OK. Public Health Perspectives of Preeclampsia in Developing Countries: Implication for Health System Strengthening. J Pregnancy. 2011; 2011: 481095.

2. Madazli R, Bulut B, Tuten A, Aydin B, Demirayak G, Kucur M. First-trimester maternal serum metastin, placental growth factor and chitotriosidase levels in pre-eclampsia. Eur J Obstet Gynecol Reprod Biol. 2012 Oct;164(2):146-9. DOI: 10.1016/j.ejogrb.2012.06.016

3. Vitoratos N, Hassiakos D, Iavazzo C. Molecular mechanisms of preeclampsia. J Pregnancy. 2012; 2012:298343. DOI: 10.1155/2012/145487 DOI: $10.1155 / 2012 / 298343$

4. Akolekar R, Zaragoza E, Poon LC, Pepes S, Nicolaides $\mathrm{KH}$. Maternal serum placental growth factor at $11+0$ to $13+6$ weeks of gestation in the prediction of pre-eclampsia. Ultrasound Obstet Gynecol. 2008 Nov;32(6):732-9. DOI: 10.1002/uog.6244

5. Bujold E, Romero R, Chaiworapongsa T, Kim YM, Kim GJ, Kim MR, et al. Evidence supporting that the excess of the sVEGFR-1 concentration in maternal plasma in preeclampsia has a uterine origin. J Matern Fetal Neonatal Med. 2005 Jul;18(1):9-16. DOI: $10.1080 / 14767050500202493$

6. Levine RJ, Lam C, Qian C, Yu KF, Maynard SE, Sachs $\mathrm{BP}$, et al. Soluble endoglin and other circulating antiangiogenic factors in preeclampsia. $\mathrm{N}$ Engl J Med. 2006 Sep 7;355(10):992-1005. DOI: $10.1056 / \mathrm{NEJ}-$ Moa055352

7. Fialova L, Malbohan IM. Pregnancy-associated plasma protein A (PAPP-A): theoretical and clinical aspects. Bratisl Lek Listy. 2002;103(6):194-205.

8. Youssef A, Righetti F, Morano D, Rizzo N, Farina A. Uterine artery Doppler and biochemical markers (PAPP-A, PIGF, sFlt-1, P-selectin, NGAL) at $11+0$ to $13+6$ weeks in the prediction of late $(>34$ weeks) pre-eclampsia. Prenat Diagn. 2011 Dec;31(12):1141-6.

9. Di Lorenzo G, Ceccarello M, Cecotti V, Ronfani L, Monasta L, Vecchi Brumatti L, et al. First trimester maternal serum PIGF, free $\beta$-hCG, PAPP-A, PP-13, uterine artery Doppler and maternal history for the prediction of preeclampsia. Placenta 2012 Jun; 33(6): 495501. DOI: 10.1016/j.placenta.2012.03.003

10. Espinoza J, Romero R, Nien JK, Gomez R, Kusanovic JP, Gonçalves LF, et al. Identification of patients at risk for 
early onset and/or severe preeclampsia with the use of uterine artery Doppler velocimetry and placental growth factor. Am J Obstet Gynecol. 2007 Apr;196(4):326.e113. DOI: $10.1016 /$ j.ajog.2006.11.002

11. Akolekar R, Syngelaki A, Poon L, Wright D, Nicolaides $\mathrm{KH}$. Competing risks model in early screening for preeclampsia by biophysical and biochemical markers. Fetal Diagn Ther. 2013;33(1):8-15. DOI: $10.1159 / 000341264$

12. Laresqoiti-Servitje E. A leading role for the immune system in the pathopysiology of preeclampsia. J Leukoc Biol 2013 Aug; 94 (2):247-57. DOI: 10.1189/ jlb. 1112603

13. Cali U, Cavkaytar S, Sirvan L, Danisman N. Placental apoptosis in preeclampsia, intrauterine growth retardation and HELLP syndrome: an immunohistochemical study with caspase-3 and bcl-2. Clin Exp Obstet Gynecol. 2013; 40 (1): 45-8.

14. Ng EK, Tsui NB, Lau TK, Leung TN, Chiu RW, Panesar NS, et al. mRNA of placental origin is readily detectable in maternal plasma. Proc Natl Acad Sci U S A. 2003 Apr 15;100(8):4748-53. DOI: 10.1073/ pnas. 0637450100

15. Tsui NB, Wong CS, Chow KC, Lo ES, Cheng YK. Investigation of biological factors influencing the placental mRNA profile in maternal plasma. Prenat. Diagn. 2014, 34, 251-258. DOI: 10.1002/pd.4300

16. Farina A. The role of RNAs and microRNAs in non-invasive prenatal diagnosis. J Clin Med 2014; 3: 440-452. DOI: $10.3390 / \mathrm{jcm} 3020440$

17. Okazaki S, Sekizawa A, Purwosunu Y, Iwasaki M, Farina A, Okai T. Measurement of mRNA of tropho- blast-specific genes in cellular and plasma components of maternal blood. J Med Genet. 2006 Sep;43(9):e47. DOI: 10.1136/jmg.2005.040634

18. Heung MM, Jin S, Tsui NB, Ding C, Leung TY, Lau TK, et al. Placenta-derived fetal specific mRNA is more readily detectable in maternal plasma than in whole blood. PLoS One. 2009 Jun 10; 4(6): e5858. DOI: 10.1371/journal.pone. 0005858

19. Sekizawa A, Purwosunu Y, Farina A, Shimizu H, Nakamura M, Wibowo N, et al. Prediction of pre-eclampsia by an analysis of placenta-derived cellular mRNA in the blood of pregnant women at 15-20 weeks of gestation. BJOG 2010, 117, 557-564. DOI: 10.1111/j.14710528.2010.02491.x

20. Farina A, Zucchini C, Sekizawa A, Purwosunu Y, de Sanctis P, Santarsiero G, et al. Performance of messenger RNAs circulating in maternal blood in the prediction of preeclampsia at 10-14 weeks. Am. J. Obstet. Gynecol. 2010, 203, e1-e7. DOI: 10.1016/j. ajog.2010.07.043

21. Available at https://www.nice.org.uk/guidance/cg107.

22. Purwosunu Y, Sekizawa A, Okazaki S, Farina A, Wibowo N, Nakamura M, et al. Prediction of preeclampsia by analysis of cell-free messenger RNA in maternal plasma. Am. J. Obstet. Gynecol. 2009, 200, doi:10.1016/j.ajog.2008.11.035. DOI: 10.1016/j. ajog.2008.11.035

23. Anton L, Olarerin-George AO, Schwartz N, Srinivas S, Bastek J, Hogenesch JB, et al. miR-210 inhibits trophoblast invasion and is a serum biomarker for preeclampsia. Am J Pathol. 2013 Nov;183(5):1437-45. DOI: 10.1016/j.ajpath.2013.07.021 